\title{
Time series of trace element distributions in planktonic foraminifer shells from the oligotrophic Gulf of Aqaba, northern Red Sea
}

\author{
NOY LEVY ${ }^{1,2}$, PROF. ADI TORFSTEIN ${ }^{1,3}$, RALF \\ SCHIEBEL $^{2}$, NATALIE CHERNIHOVSKY ${ }^{1,3}$, KLAUS \\ PETER JOCHUM $^{2}$, ULRIKE WEIS ${ }^{2}$, BRIGITTE STOLL ${ }^{2}$ \\ AND GERALD H. HAUG ${ }^{2,4}$
}

${ }^{1}$ Hebrew University of Jerusalem

${ }^{2}$ Max Planck Institute for Chemistry

${ }^{3}$ The Interuniversity Institute for Marine Sciences in Eilat

${ }^{4}$ ETH Zurich

Presenting Author: n.levy@mpic.de

The trace element chemistry of planktonic Foraminifera (PF) shells records the seawater composition and conditions of the marine environment in which they grow. Yet, long term in situ calibration and interspecies differences in proxy systematics are still poorly constrained, hampering the use of trace element distributions as environmental tracers of modern and past oceanic conditions.

Here, we report element ratios using laser ablation mass spectrometry (LA-ICP-MS) in PF shells collected using monthly resolved sediment traps at various water column depths in the northern part of the Gulf of Aqaba (GOA) in 2014 and 2015. In particular, we focus on Calcium-normalized elemental abundances in different morphotypes of the two abundant species Globigerinoides ruber and Turborotalita clarkei.

The results show that inter-chamber cation/Ca variability is lower in G. ruber relative to T. clarkei. In general, $\mathrm{Mg} / \mathrm{Ca}$ in $G$. ruber display a positive correlation with temperature over time and depth. This general relationship does not exist in T. clarkei, which displays strong positive $\mathrm{Mg} / \mathrm{Ca}$ perturbations in the subsurface water column, likely reflecting the impact of bottom sediment resuspension events during winter. B/Ca in G. ruber and $T$. clarkei displays a gradual first-order decrease over time that roughly corresponds with surface water $p \mathrm{H}$ patterns. By contrast, $\mathrm{Sr} / \mathrm{Ca}$ remains constant around $1.5 \mathrm{mmol} / \mathrm{mol}$ between the chambers, species, and over time and different water depths.

$\mathrm{Al} / \mathrm{Ca}, \mathrm{Ti} / \mathrm{Ca}, \mathrm{Mn} / \mathrm{Ca}$, and $\mathrm{Fe} / \mathrm{Ca}$ co-vary, most likely reflecting the control of terrigenous end members, while $\mathrm{B} / \mathrm{Ca}$, $\mathrm{Mg} / \mathrm{Ca}$, and $\mathrm{Na} / \mathrm{Ca}$ vary independently, each assumed to be controlled by different environmental processes. The results are evaluated in the context of oceanic properties and characteristic seawater trace element compositions, in order to improve their application as environmental tracers and paleo-proxies. 